\title{
Labour migrant adjustments in the aftermath of the financial crisis
}

\author{
Bernt Bratsberg, Oddbjørn Raaum, and Knut Røed \\ The Ragnar Frisch Centre for Economic Research
}

\begin{abstract}
Based on individual longitudinal data, we examine the evolution of employment and earnings of post-EU accession Eastern European labour immigrants to Norway for a period of up to eight years after entry. We find that the migrants were particularly vulnerable to the negative labour demand shock generated by the financial crisis. During the winter months of $2008 / 09$, the fraction of immigrant men claiming unemployment insurance benefits rose from below 2 to 14 per cent. Some of this increase turned out to be persistent, and unemployment remained considerably higher among immigrants than natives even three years after the crisis. Although we find that negative labour demand shocks raise the probability of return migration, the majority of the labour migrants directly affected by the downturn stayed in Norway and claimed unemployment insurance benefits.
\end{abstract}

Acknowledgements: This research has been supported by grants from the Nordic Council, the Norwegian Ministry of Labour (project "Labour Migration to Norway") and the Norwegian Research Council (project "Social Insurance and Labour Market Inclusion in Norway," Grant No. 202513). Data made available by Statistics Norway have been essential for the empirical analyses. 


\section{Introduction}

The common Nordic labour market of 1954 has for 60 years facilitated unrestricted worker mobility within the Nordic countries. Over the decades, the integrated labour market has raised overall employment in the Nordic region by smoothing asymmetric labour demand shocks, serving as an important stabilizing force of macroeconomic fluctuations. Inter-Nordic migration flows are cyclical (Pedersen and Røed, 2008) and reduce pressures on wages and prices during booms in the receiving country (Lundborg, 2006), while providing employment opportunities in other countries for those affected by recessions at home.

The subsequent extensions of the common labour market - first with other countries in Western Europe in 1994 through the establishment of the European Economic Area (EEA), and then with countries in Eastern and Central Europe in 2004 and 2007 through the expansions of the European Union - have significantly enlarged the potential benefits associated with free movement of labour (for a recent analysis of the effects of open borders on productive efficiency, see Kennan 2013). This comes at a time when the Nordic countries are going through a period of rapid demographic transition with ageing of the population, high exit rates from the labour force, and consequently temporary labour shortages in many occupations and industries. In this light, labour immigration offers a potential remedy to fiscal imbalances created by demographic changes (Storesletten, 2003; Holmøy and Strøm, 2012; Dustmann and Frattini, 2013; Preston, 2013).

But the recent enlargements of the common labour market have also brought new challenges. Whereas the common Nordic labour market as well as the EEA prior to 2004 represented open borders between countries with fairly similar wage levels and welfare structures, the 2004 and 2007 EU expansions meant that the common market now includes countries that are widely different along these dimensions. The opening of borders and permitting unregulated labour migration between countries characterized by huge differences in economic conditions represents a rather unique experiment. Large wage and social insurance differentials between the Nordic countries and the home country - combined with regulation that ensures exportability of social insurance entitlements - means that effective replacement rates can become very high, particularly when benefits are collected in the Nordic countries while consumption expenditures are in Eastern European prices. From a theoretical perspective, under such conditions work incentives will be weakened and the economic gains from staying in the destination country beyond the expiration of the initial spell of employment can be considerable. 
Historically, inter-Nordic labour migrants working in a neighbouring country have typically returned home when employment opportunities deteriorate, presumably because the gains from staying on are small when social insurance systems of the two countries are comparable. Empirical evidence on the medium-term labour market performance and return migration propensity of the new labour migrants from Eastern Europe is, however, scarce. Because of the lack of relevant historical parallels, it has been difficult to foresee the size and composition of resulting migration flows, as well as how migrant workers will react to cyclical fluctuations in the host country.

This chapter first provides a descriptive overview of the recent migration flows to the Nordic countries highlighting the significant changes that occurred in response to the EU expansion in 2004, addressing the possible incentives embedded in the large differences in earnings levels and social insurance institutions between the Nordic and Eastern European countries. We then focus more closely on labour immigrants to Norway, and document the labour market performance of post-EU accession Eastern European labour migrants during their first years in the country by means of longitudinal administrative micro data. We examine in greater detail the migrants that came to Norway from Poland and the Baltic States between 2004 and 2007, following accession but prior to the onset of the financial crisis. As the financial crisis hit the Norwegian labour market in late 2008, we study how the negative labour demand shock affected subsequent employment and earnings patterns and the propensity to leave Norway. Did the financial crisis impinge on migrant inflows? How did labour migrants present in Norway at the time of the crisis adjust to the economic downturn; did migrant workers directly affected by the economic crisis stay and collect unemployment benefits, or did they return migrate to their home country? Did the crisis affect longterm economic outcomes such as employment, earnings, and welfare benefit uptake among the labour immigrants?

\section{The 2004 EU expansion and immigration to the Nordic countries}

The 2004 eastward enlargement of the European Union bolstered immigration from the accession countries to the Nordic region. This is highlighted in Figure 1, which shows that each of the five Nordic countries experienced significant increases in inflows from the new EU member states in the years following accession. In fact, between 2003 and 2008, overall immigration from the new member states to the Nordic region increased from 8,000 to 58,000 per year (Tronstad and Andersson Joona, 2013). As the figure shows, inflows are unevenly distributed across destination countries, with Norway and Sweden receiving the bulk of migrants from the new EU member states 


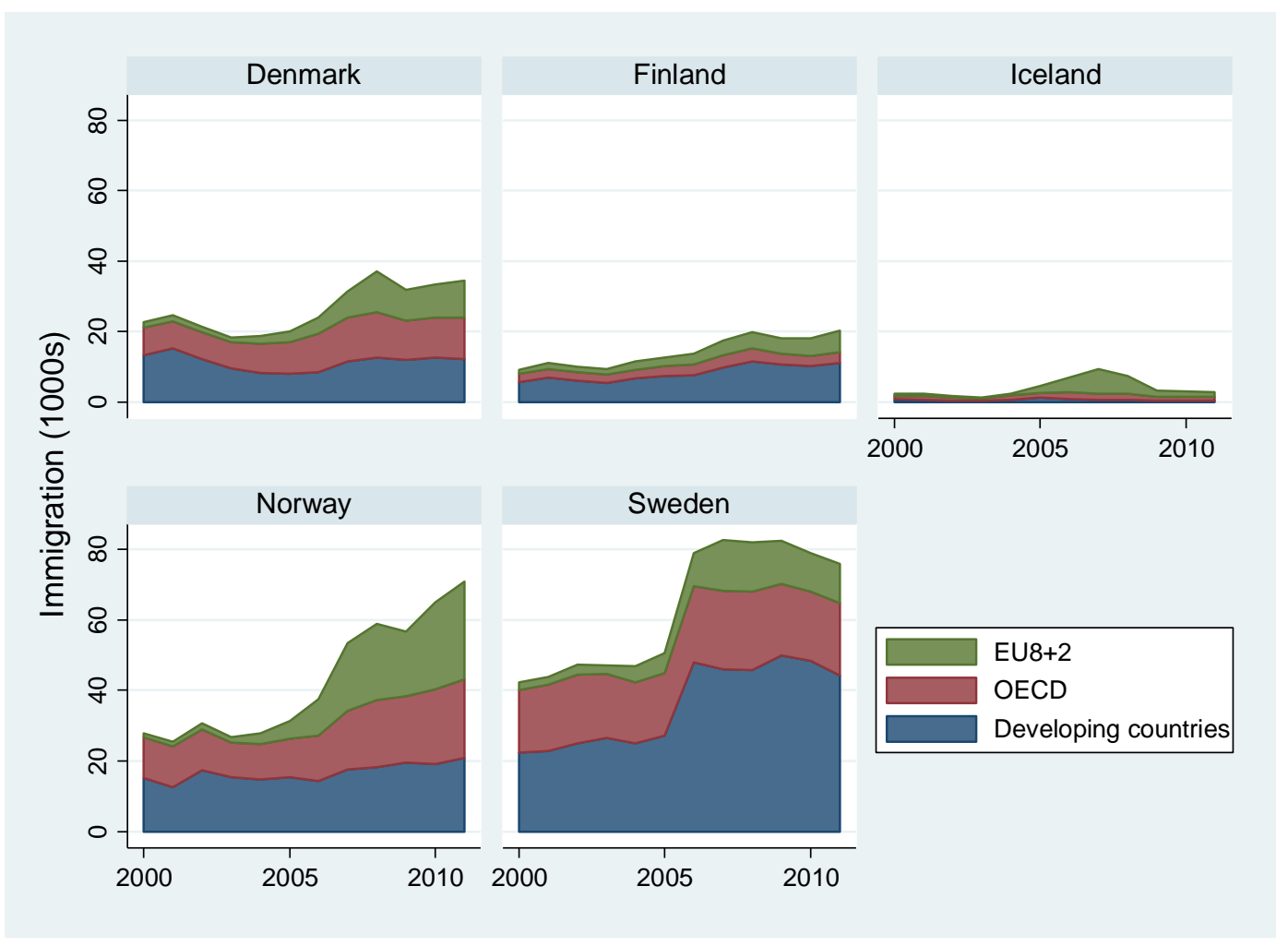

Figure 1: Immigration to the Nordic countries by major region of origin, 2000-2011

Source: OECD International Migration Statistics

Note: "EU8+2" includes Bulgaria, the Czech Republic, Estonia, Hungary, Latvia, Lithuania, Poland, Romania, Slovakia, and Slovenia.

(and two thirds of the overall Nordic inflow in 2007). The figure also bears witness to the slowdown of this migrant flow in 2009, immediately following the crisis. The flow nevertheless quickly recovered and by 2011 was back to its pre-crisis level in all countries except Iceland.

The overall fraction of immigrants in the population is also rising considerably in the Nordic countries, particularly in Norway, Sweden, and Iceland (at least up until the financial crisis), where the immigrant population shares in 2011 were between 12 and 15 per cent; see Figure 2. Finland is an important exception to this pattern, however, with an immigrant population share in 2011 slightly below 5 per cent. Given the large inflows from Eastern Europe since 2004, the population share from accession countries is rising throughout the Nordic region. Nevertheless, with the exception of Iceland, those originating in developing countries made up the largest immigrant groups as of 2011, with population shares ranging from 2 per cent in Finland to 6 per cent in Norway. Differences in 2011 population shares will reflect both variations in the initial stock of migrants as well as the 


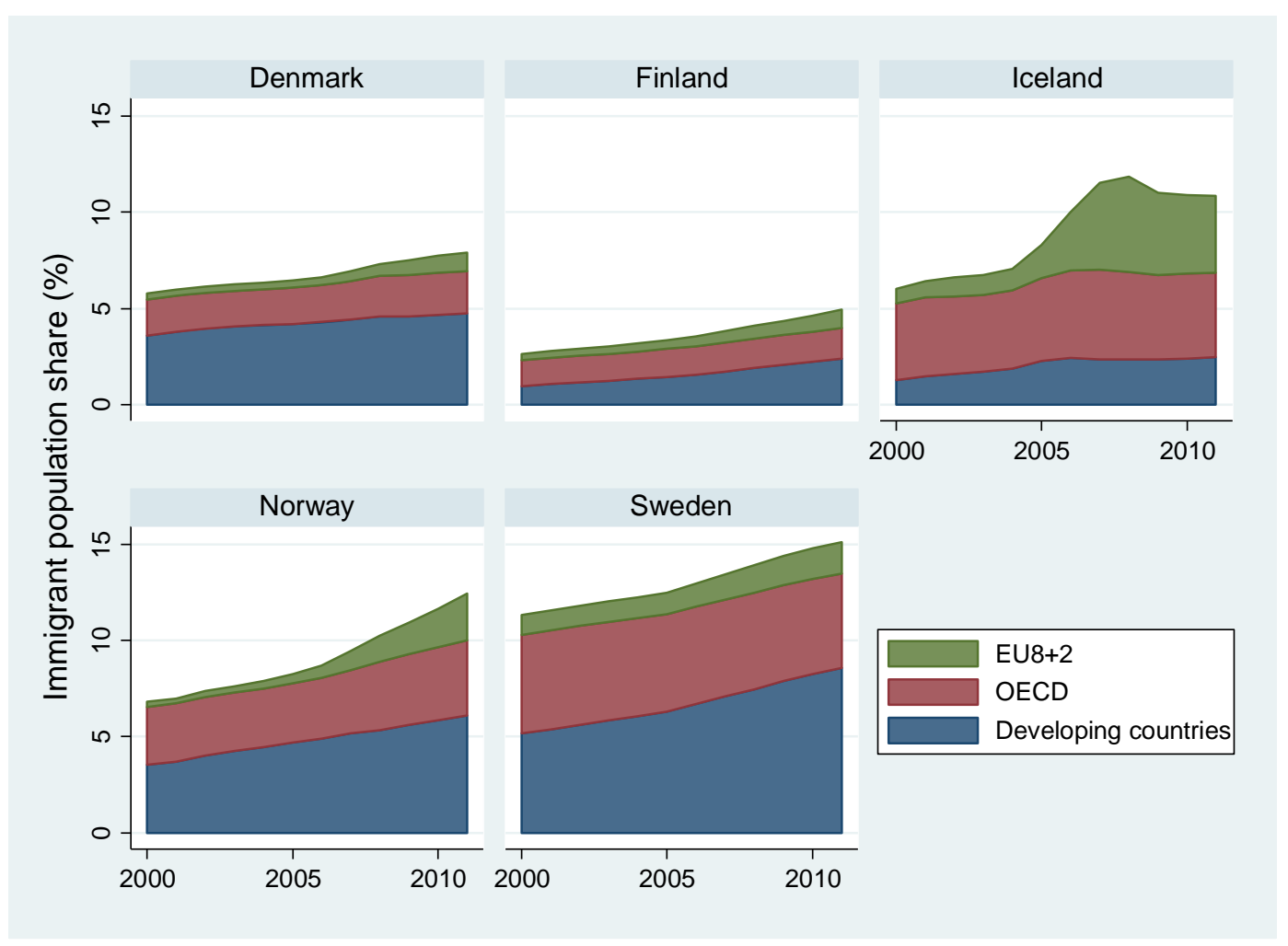

Figure 2: Immigrant population shares in the Nordic countries by major region of origin, 2000-2011

Source: OECD International Migration Statistics; Statistics Denmark

Note: "EU8+2" includes Bulgaria, the Czech Republic, Estonia, Hungary, Latvia, Lithuania, Poland, Romania, Slovakia, and Slovenia.

generally lower propensity to remigrate observed among immigrants from developing countries. (For analyses of labour market integration and welfare use among immigrants to the Nordic countries from developing and developed countries, see Edin et al., 2000; Husted et al., 2001; Hansen and Lofström, 2003; Bratsberg et al., 2010; Sarvimäki, 2011; Barth et al., 2012.) When we use the micro data that form the basis for the analyses of the next sections and examine immigrant employment in Norway (these data are not available to the authors for the remaining Nordic countries), we find that immigrant population shares in general are mirrored in their labour force shares. These data reveal, however, a somewhat larger weight for recent immigrants from accession countries who in 2011 made up 3.2 per cent of the labour force versus 2.4 per cent of the population. In comparison, immigrants from developing countries accounted for 5.8 per cent of the labour force, slightly less than their 6 per cent population share. 
Economic theory since Sjaastad (1963) emphasizes that migrant flows respond to economic conditions in source and destination countries, and empirical studies confirm this prediction (see, e.g., Pedersen et al., 2008; Mayda, 2010). Differences in employment opportunities and wage differentials are among the most important factors determining migration behaviour. In addition, differences in social insurance institutions may motivate migration, particularly for risk averse persons and for persons who consider it likely that they may become reliant on social insurance transfers (Nannestad, 2004; Barrett, 2012). Within the common European labour market, this may be of particular importance, as EU rules on social security coordination ensure that entitlements in general are transferred to the country of (most recent) employment. This regulation implies that Eastern European labour immigrants to, say, the Nordic countries immediately gain access to the same welfare transfers (such as child allowances) and insurance programs (e.g., unemployment insurance) as natives (see the discussion in NOU, 2011, and European Commission, 2013).

Table 1 illustrates the potential importance of these incentives by reporting average monthly wage earnings and unemployment benefits in the Nordic countries as well as in the major migrant source countries in Eastern Europe (Poland and the Baltic states). Not surprisingly, a job in one of the Nordic countries pays many times more than a job in one of the four listed source countries. But, even the

Table 1: Unemployment benefits and average earnings in the Baltic States, Poland, and the Nordic countries, 2010

(I)

Single wage earner, no children

Monthly UI benefits

405

411

188

223

2,188

1,584

1,547

2,948

1,545
(II)

(III) (IV)

Wage earner in married couple, two children Monthly family wage income if employed

benefits employed

$\begin{array}{lllll}\text { Denmark } & 2,188 & 4,208 & 2,188 & 7,028 \\ \text { Finland } & 1,584 & 3,283 & 1,737 & 5,483 \\ \text { Iceland } & 1,547 & 2,793 & 1,547 & 4,664 \\ \text { Norway } & 2,948 & 4,916 & 3,040 & 8,210 \\ \text { Sweden } & 1,545 & 3,217 & 1,545 & 5,373\end{array}$

Note: Source OECD iLibrary, OECD Social and Welfare Statistics. Benefits and wages are converted to Euros using average exchange rate for 2010. Columns (III) and (IV) are computed as if spouse earns $67 \%$ of average wage. 
typical level of unemployment insurance benefits in the Nordic countries by far exceeds average wage earnings in Poland and the Baltics. For example, for a single wage earner without children, the average unemployment insurance benefit level in Norway is five times higher than average wage earnings in Lithuania and four times higher than average earnings in Poland. Although some of these differentials will be mitigated by the higher living costs in the Nordic countries, the large differences in pay and benefits across countries will affect incentives for return migration in case of loss of employment.

To give an overview of the state of the labour markets during the relevant period, in Figure 3 we show recent developments of unemployment in each of the Nordic countries and in two of the major source countries, Poland and Estonia. Between 2004 and the onset of the financial crisis in the fall of 2008, there was a general reduction and strong convergence in unemployment rates across the seven countries. In the period following the crisis, unemployment grew in all of the countries, but to higher levels in the new EU member states than in the Nordic region. As the figure also shows, compared to the rest of the Nordic region, the crisis had a relatively modest impact on the

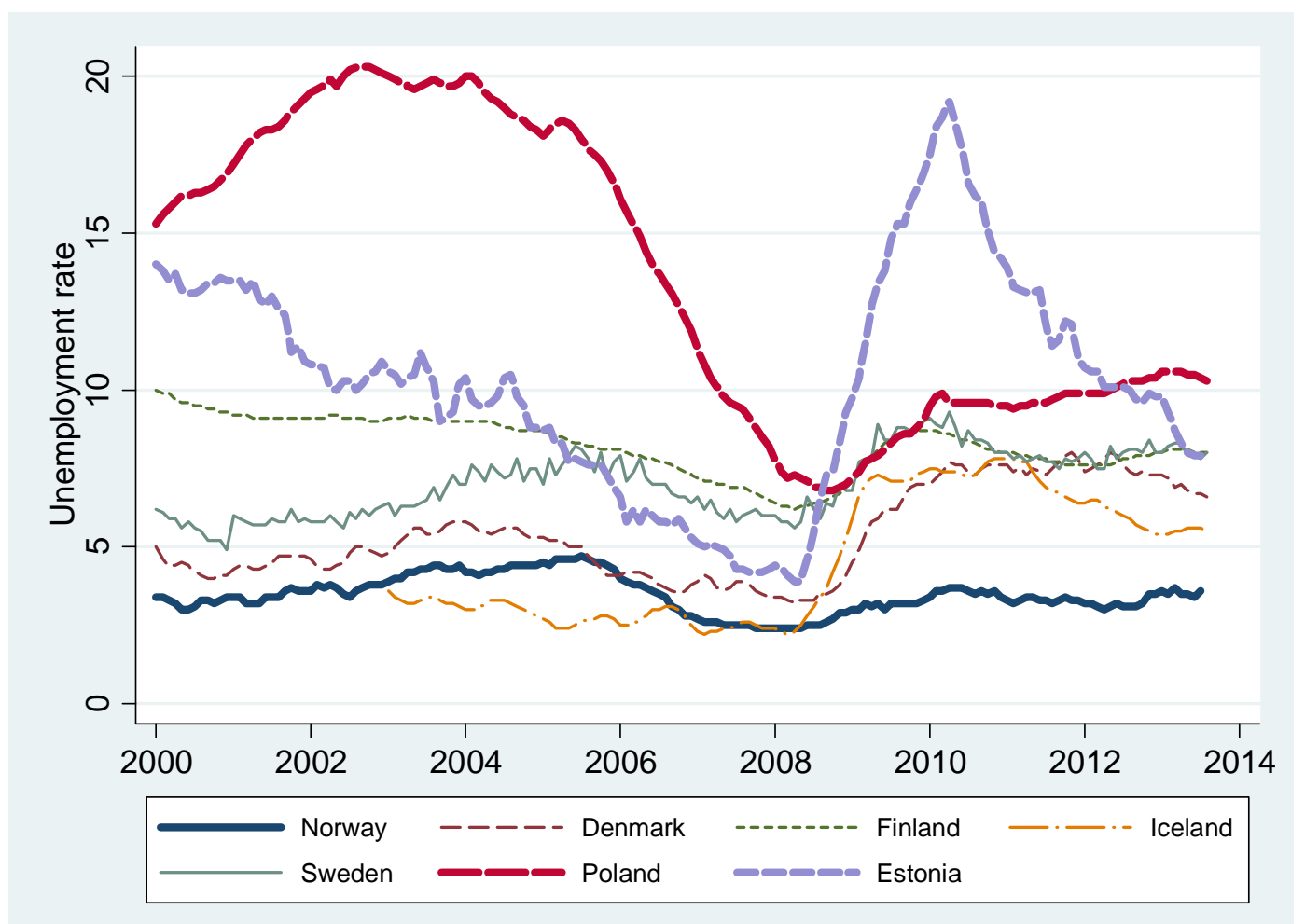

Figure 3: Unemployment rates in the Nordic countries, Poland, and Estonia, Jan 2000-July 2013 
Norwegian economy. The higher unemployment rates in the new EU member states and the favourable employment conditions in Norway provide suggestive evidence that the financial crisis had a modest impact on migration flows; if anything, the crisis reinforced pre-existing relative differences in labour market conditions in sending and receiving countries.

\section{Labour migration to Norway}

The eastward enlargements of the EU and, thereby, the EEA in 2004 and 2007 extended the integrated European labour market and workers of the new member states were no longer constrained to enter Norway as seasonal workers or specialists, the two major admission classes before accession. Several continental countries met the EU expansions by imposing restrictive transitional arrangements based on quotas and employment requirements. Such transitional arrangements caused substantial diversion effects, reinforcing inflows to the UK and Ireland in particular (Boeri and Brücker, 2005). The Norwegian transitional arrangements, like those in Denmark, were fairly liberal for individual migrants, allowing for up to six months of job search at their own expense. Permits to stay for work were granted to anyone who could document a fulltime job with pay and working conditions in accordance with collective agreements or "what normally applied" in the industry of employment (Dølvik and Eldring, 2005). Work permits lasted until the work contract expired and gave the right to a subsequent six months of job search, but EU8+2 citizens were not eligible for unemployment insurance until after 12 months of employment (see also the discussions in Hansen et al., 2010, and Friberg and Eldring, 2013).

The transitional arrangements were set to expire after five years, and were repealed on May 1, 2009, for citizens from the EU8 (Poland, Lithuania, Latvia, Romania, Estonia, the Czech Republic, Slovakia, and Hungary), and in 2012 for Romanian and Bulgarian citizens. Following the transitional period, migrant and native workers face the same eligibility criteria for unemployment insurance. Specifically, the UI program is available for active job seekers who have lost their job involuntarily. To become eligible, job seekers must have had labour earnings exceeding 1.5 times the social insurance base amount (presently 123,183 NOK or $€ 16,500$ ) during the prior calendar year or earnings that add up to at least 3 times the base amount over the three calendar years prior to unemployment entry. Labour earnings from the origin country are adjusted upwards to account for the general wage difference between countries, implying that earnings from a job in, say, Poland, will be recalculated to the level that would have applied had the same job been held in Norway. 
The strong economic upturn in Norway between 2005 and 2008, when unemployment dropped from 4.7 per cent in October 2005 to 2.4 per cent in May 2008 led to unprecedented inflows of labour migrants from the accession countries. Between 2003 and 2008, immigration from the new EU member states grew from 1.5 to 21 thousand per year. In total, between 2005 and 2008, 57 thousand immigrants from the accession countries took up residence in Norway. The period saw similar growth in temporary labour migrant inflows (Bratsberg et al., 2013). Figure 4 shows the developments in immigrant inflows from the five major source countries in Eastern Europe as well as the rest of the EU8+2 area. As is evident from the figure, Poland is by far the major source country of this migrant flow, with Lithuania growing in importance since 2009.

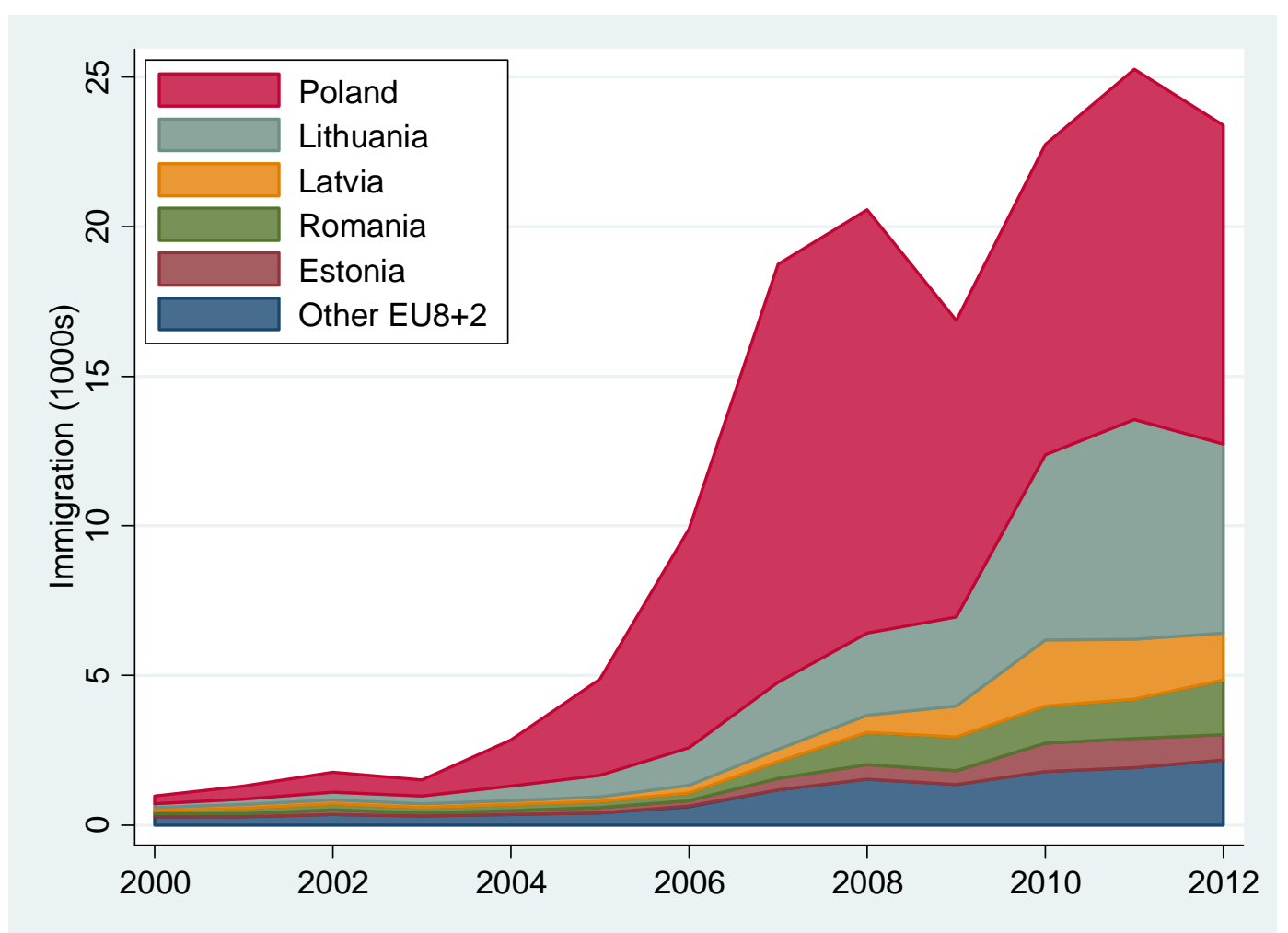

Figure 4: Immigration to Norway from new EU member states, 2000-2012

Source: Authors' calculations from population register data.

\section{Data and analyses samples}

The analysis in this chapter is based on longitudinal individual records drawn from several administrative registers of the full population. The data sources include the population register with 
information on age, gender, nationality, and date of immigration; tax registers with detailed accounts of annual labour earnings and transfers; employer-employee registers with information on on-thejob tenure and industry of employment; social insurance registers with information on registered unemployment spells and unemployment insurance claims; and, finally, the national education database with information on the highest completed educational attainment. The different data sources are linked together by means of an encrypted common identification number.

Table 2 describes the composition of the labour migrant cohorts from the four major source countries during the post-accession and pre-crisis period between 2004 and 2008 - Poland and the three Baltic States. Among the male migrants in the relevant age group (17-46), 23.1 per cent had left Norway by January 1, 2010 (see column III, which reports the fraction that remained in Norway). Outmigration was even lower among women; 14.7 per cent of the equivalent group had left Norway by 2010 . In the next sections, we study the link between individual adverse earnings and employment shocks triggered by the financial crisis and outmigration behaviour. This analysis is

Table 2: Immigrant inflows from Estonia, Latvia, Lithuania, and Poland, 2004-2007

(l)

\begin{tabular}{|c|c|c|c|c|c|c|c|}
\hline $\begin{array}{l}\text { Year of } \\
\text { arrival }\end{array}$ & Cohort size & $\begin{array}{c}\text { Per cent } \\
\text { age } 17-46 \\
\text { at arrival }\end{array}$ & $\begin{array}{l}\text { Per cent in } \\
\text { Norway } \\
1.1 .2010 \text { if } \\
\text { (II) }\end{array}$ & $\begin{array}{c}\text { Per cent } \\
\text { w/ } \\
\text { wages }>1 \mathrm{G} \\
\text { in } 2008 \text { if } \\
\text { (III) }\end{array}$ & $\begin{array}{c}\text { Obs in out- } \\
\text { migration } \\
\text { analysis }\end{array}$ & $\begin{array}{c}\text { (VI) } \\
\text { Per cent } \\
\text { out- } \\
\text { migrated } \\
\text { by } \\
1.1 .2013 \text { if } \\
\text { (V) }\end{array}$ & $\begin{array}{c}\text { (VII) } \\
\text { Obs in } \\
\text { unemploy- } \\
\text { ment and } \\
\text { earnings } \\
\text { analyses } \\
\text { (in Norway } \\
1.1 .2013 \text { ) }\end{array}$ \\
\hline \multicolumn{8}{|l|}{ A. Men } \\
\hline 2004 & 1,390 & 82.1 & 76.8 & 81.3 & 712 & 6.7 & 664 \\
\hline 2005 & 3,041 & 81.8 & 79.9 & 82.9 & 1,649 & 5.2 & 1,564 \\
\hline 2006 & 6,781 & 81.0 & 76.7 & 84.3 & 3,553 & 5.9 & 3,342 \\
\hline 2007 & 12,900 & 81.6 & 76.3 & 88.0 & 7,068 & 8.4 & 6,475 \\
\hline Total & 24,112 & 81.5 & 76.9 & 85.9 & 12,982 & 7.2 & 12,045 \\
\hline \multicolumn{8}{|c|}{ B. Women } \\
\hline 2004 & 859 & 83.2 & 75.9 & 75.9 & 412 & 1.5 & 406 \\
\hline 2005 & 1,168 & 79.1 & 80.4 & 70.4 & 523 & 1.5 & 515 \\
\hline 2006 & 2,240 & 75.6 & 86.7 & 65.2 & 957 & 4.0 & 919 \\
\hline 2007 & 4,036 & 75.3 & 88.3 & 59.0 & 1,585 & 3.7 & 1,527 \\
\hline Total & 8,303 & 76.8 & 85.3 & 63.9 & 3,477 & 3.2 & 3,367 \\
\hline
\end{tabular}


based on labour migrants who had not left and remained in Norway at the beginning of 2010, and who were solidly established in the labour market before the financial crisis, earning at least the base amount of the public pension system during 2008 (see Table 2, cols IV and V). We also study longterm employment and earnings among those we remained in Norway over time; these analyses are based on the longitudinal panel of individuals who were present in Norway as of 1.1.2013 (see column VII).

\section{Individual earnings shocks during the financial crisis}

The financial crisis hit the Norwegian labour market, and especially the construction sector, in late 2008. In this section, we investigate how the crisis affected employment and earnings among recently arrived labour immigrants. To place the migrant outcomes in perspective, we compare their outcomes with those of similar natives. For this purpose, we construct male and female native comparison groups that exactly match the age distribution of the immigrant samples. Because there may be large differences in educational attainment between immigrants and natives, and because it is unclear whether recently arrived immigrants earn similar returns on their educational investments as natives, we also construct native comparison groups consisting of persons with very low education; i.e., those who did not complete upper secondary education. Unfortunately, data on educational attainment is missing for a majority of the migrant samples. For those with education data, average attainment lies somewhere between the averages of the two native comparison groups.

Prior research shows that labour migrants are particularly vulnerable to economic downturns (Barth et al., 2004; Dustmann et al., 2010). Such differences in their sensitivity to the stage of the business cycle may arise because immigrants are more likely to hold temporary job contracts and, because of their generally shorter tenure with the employer, are more often adversely affected by last-in-firstout practices. Immigrants are also more likely than natives to hold jobs in industries, such as construction, that are vulnerable to business cycle fluctuations.

To study the role of adverse individual employment and earnings shocks, we focus on those with a solid foothold in the labour market prior to the financial crisis and who were employed in 2008 with pay exceeding the base amount of the public pension system. Among migrants and natives employed in 2008, we define a negative earnings shock as either being non-employed in 2009 or having experienced a drop in real labour earnings of more than 50 per cent from 2008 to 2009. In our samples of male workers, 17.8 per cent of the labour migrants experienced this negative income 
shock, while native males were considerably less affected (4.0 per cent); see Table 3 , column 1 . This observed difference can in part be explained by the fact the immigrants in question on average tended to have shorter tenure (and, hence were disproportionally affected by last-in-first-out practices) and also worked in industries that were hit particularly hard by the financial crisis. When we regress an indicator variable of the individual negative employment shock during the financial crisis on immigrant status, and control for tenure and industry (the latter by means of 504 indicator variables for detailed industry of employment before the crisis), the male immigrant-native differential falls from 13.9 to 9.0 percentage points (see Table 3, Panel A, column II). When we also condition on pre-crisis wages (to account for the fact that those with low wages may be more

Table 3: Accounting for immigrant-native difference in probability of negative earnings shock during the financial crisis

\begin{tabular}{|c|c|c|c|c|c|c|}
\hline & (I) & $\begin{array}{l}\text { (II) } \\
\text { Men }\end{array}$ & (III) & (IV) & $\begin{array}{c}\text { (V) } \\
\text { Women }\end{array}$ & (VI) \\
\hline \multicolumn{7}{|l|}{ Immigrants } \\
\hline $\begin{array}{c}\text { Share with negative } \\
\text { earnings shock }\end{array}$ & 0.178 & & & 0.077 & & \\
\hline \multicolumn{7}{|l|}{ A. All natives } \\
\hline $\begin{array}{c}\text { Share with negative } \\
\text { earnings shock }\end{array}$ & 0.040 & & & 0.046 & & \\
\hline $\begin{array}{l}\text { Immigrant-native } \\
\text { difference }\end{array}$ & $\begin{array}{c}0.139 * * * \\
(0.003)\end{array}$ & $\begin{array}{c}0.090 * * * \\
(0.003)\end{array}$ & $\begin{array}{c}0.071 * * * \\
(0.003)\end{array}$ & $\begin{array}{c}0.031 * * * \\
(0.004)\end{array}$ & $\begin{array}{c}0.013^{* * *} \\
(0.005)\end{array}$ & $\begin{array}{c}0.004 \\
(0.005)\end{array}$ \\
\hline Tenure/10 & & $\begin{array}{c}-0.035 * * * \\
(0.003)\end{array}$ & $\begin{array}{c}0.000 \\
(0.003)\end{array}$ & & $\begin{array}{c}-0.036 * * * \\
(0.006)\end{array}$ & $\begin{array}{l}0.011^{*} \\
(0.006)\end{array}$ \\
\hline $\begin{array}{l}\text { In(annual wages } \\
\text { 2008) }\end{array}$ & & & $\begin{array}{c}-0.130 * * * \\
(0.003)\end{array}$ & & & $\begin{array}{c}-0.101^{* * *} \\
(0.003)\end{array}$ \\
\hline \multicolumn{7}{|l|}{ B. Low educ natives } \\
\hline $\begin{array}{c}\text { Share with negative } \\
\text { earnings shock }\end{array}$ & 0.073 & & & 0.066 & & \\
\hline $\begin{array}{l}\text { Immigrant-native } \\
\text { difference }\end{array}$ & $\begin{array}{c}0.105^{* * *} \\
(0.004)\end{array}$ & $\begin{array}{c}0.046 * * * \\
(0.006)\end{array}$ & $\begin{array}{c}0.042 * * * \\
(0.005)\end{array}$ & $\begin{array}{c}0.011^{* *} \\
(0.006)\end{array}$ & $\begin{array}{l}-0.003 \\
(0.007)\end{array}$ & $\begin{array}{l}-0.000 \\
(0.007)\end{array}$ \\
\hline Tenure/10 & & $\begin{array}{c}-0.065^{* * *} \\
(0.007)\end{array}$ & $\begin{array}{l}-0.002 \\
(0.007)\end{array}$ & & $\begin{array}{c}-0.039 * * * \\
(0.015)\end{array}$ & $\begin{array}{l}0.016 \\
(0.015)\end{array}$ \\
\hline $\begin{array}{l}\text { In(annual wages } \\
\text { 2008) }\end{array}$ & & & $\begin{array}{c}-0.207 * * * \\
(0.005)\end{array}$ & & & $\begin{array}{c}-0.124^{* * *} \\
(0.007)\end{array}$ \\
\hline $\begin{array}{l}\text { Additional control } \\
\text { variables }\end{array}$ & None & $\begin{array}{l}\text { Industry } \\
\text { (504 cat's) }\end{array}$ & $\begin{array}{l}\text { Industry } \\
\text { (504 cat's) }\end{array}$ & None & $\begin{array}{l}\text { Industry } \\
\text { (462 cat's) }\end{array}$ & $\begin{array}{l}\text { Industry } \\
\text { (462 cat's) }\end{array}$ \\
\hline
\end{tabular}

*/**/*** Significant at the 10/5/1 per cent level.

Note: Standard errors are reported in parentheses. Samples are restricted to those with wage earnings above $1 \mathrm{G}$ in 2008 and who were present in Norway 1.1.2010. The regressions have 49,549 (panel A, cols I-III), 25,493 (panel A, cols IV-VI), 24,060 (panel B, cols I-III), and 7,929 (panel B, cols IV-VI) observations. 
exposed to negative earnings shocks), the differential drops to 7.1 per cent (see column III). Still, the estimates presented in Table 3 reveal that labour migrants are much more exposed to negative labour demand shocks, compared to natives with the same age, tenure, earnings, and industry affiliation. Educational attainment is not observed for these immigrant cohorts, but if we compare the migrants with low-educated natives (without completed upper secondary education), the differential remains significant at 4.2 percentage points; see panel B column (III).

Compared to males, females were less adversely affected by the financial crisis as only 7.7 per cent of employed immigrant women experienced a negative income shock during the crisis. Among employed native women, 4.6 per cent experienced the adverse earnings shock (see column IV). When we account for differences in tenure and industry affiliation, the female immigrant-native differential is reduced by more than a half; see Table 3 panel A, column (V). Further controlling for 2008 wages, there is no difference in income shock exposure between the samples of immigrant and native women, regardless of whether we compare immigrants with natives with average attainment (panel A) or low-educated native women (panel B).

The rise in unemployment following the financial crisis was particularly steep for the labour migrants. This is depicted in Figure 5, which shows that the share of the migrant group with unemployment benefits rose dramatically over a short time period - from below 2 per cent in October 2008 to 14 per cent in February 2009. Male unemployment peaked during the winter months of 2010, with unemployment rates of 18.4 per cent among immigrants, 8.1 per cent among low-educated natives, and 3.4 per cent in the native sample with average educational attainment. Even if immigrant unemployment dropped significantly during the recovery period in 2011-2012, it never returned to its pre-crisis level and remained persistently above the corresponding rates for the two native comparison groups. As was also shown in Table 3, the crisis had less severe consequences for female immigrants. But, even if the rise in unemployment was less dramatic than for men, unemployment remained at a high level, and by 2013 the unemployment rate was actually significantly higher among female than among male immigrants. When we consider the incidence of unemployment over the entire 2009-2012 period, we find that 46 per cent of the male labour migrants present in Norway at the end of 2009 received UI benefits at some point during the extended period, compared to 22 per cent of low-educated native men and 12 per cent of the comparison group of native men with average attainment. For women, the corresponding figures of cumulative unemployment incidence are 27 per cent for immigrants, and 20 and 10 per cent for the two comparison groups of low and average educated native women, respectively. 


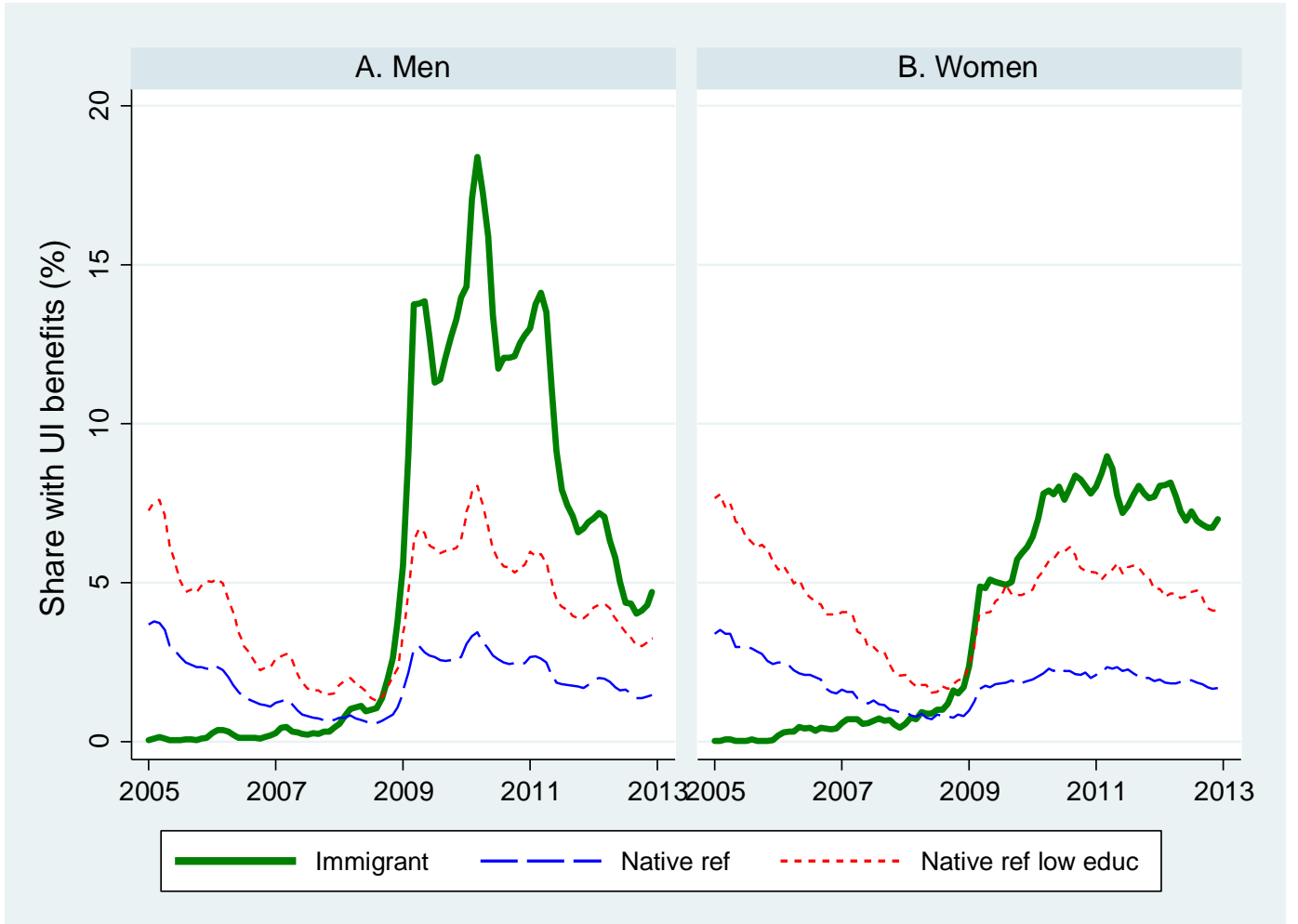

Figure 5: Unemployment rate at end of month, Jan 2005-Dec 2012

Note: Immigrant samples consist of 2004-2007 migrants from Poland, Lithuania, Latvia, and Estonia; age 17-46 at arrival; employed in 2008 with labour earnings exceeding NOK 69,108; and present in Norway 1.1.2013. Native samples are subject to the same employment and earnings restrictions, and are stratified to match the age distribution of the immigrant samples.

To summarize, while unemployment among male labour migrants was negligible during the initial period after arrival and prior to the financial crisis, five to eight years after arrival unemployment was considerably higher among immigrants than among natives for both women and men, even when we compare immigrants to natives with basically no qualifying education.

\section{Adverse earnings shocks and outmigration}

The long-term economic effects of labour migration depend on the extent to which immigrants stay or outmigrate in response to economic shocks that undermine the employment opportunities that motivated migration in the first place (for studies of outmigration among immigrants to Sweden and Norway, see Nekby, 2006, and Bratsberg et al., 2007). From a public finance perspective, the interaction between labour market outcomes and duration of stay is particularly important. In this 
section we study outmigration patterns among the labour migrants and how these patterns are related to individual adverse earnings shocks triggered by the financial crisis.

To study the role of adverse earnings shocks for outmigration decisions, we again focus on the samples of immigrants with a foothold in the Norwegian labour market prior to the financial crisis and who remained in Norway at least until January 1, 2010. The latter sample restriction likely makes us understate the relationship as we ignore outmigrations that took place immediately after the economic downturn. (The underlying micro data reveal that 5.1 per cent of post-accession male labour migrants who were employed in 2008 outmigrated during 2009. The figure compares to an outmigration rate of 4.7 per cent in 2007 and 2008 when we consider those employed during the prior year. These figures suggest that the number of labour migrants to outmigrate during the short term in response to the economic downturn was negligible.) But the restriction allows us to circumvent the problem of reverse causality, as we drop from the analysis those who left their job because they already had decided to outmigrate. As Table 2 showed, 7.2 per cent of the male migrants who remained present in Norway as of January 1, 2010, outmigrated during the following 36 months. Among women, only 3.2 per cent outmigrated.

In this section, we examine the extent to which outmigration decisions were affected by experiences of adverse earnings shocks, and in particular whether these effects were moderated by receipt of unemployment insurance benefits. Table 4 presents the estimation results from a linear probability model where the dependent variable is an indicator set to unity if the persons outmigrated between Jan 1, 2010, and Dec 31, 2012 (and zero otherwise). The results reveal that loss of employment with a substantial negative earnings shock in 2009 had a significant effect on subsequent outmigration for both men and women. The effect was much larger for those who did not claim UI benefits in 2009 than for those who did. For male labour migrants, the combined effect of earnings loss and UI benefits raised the outmigration rate by 6 percentage points, yielding an outmigration propensity that is more than twice that of the reference group. (Recall that the reference group consists of those with stable employment during the financial crisis; their outmigration rate was 4.4 per cent, see constant, column I.) Female outmigration is also affected with a combined effect of earnings loss and $\mathrm{UI}$ benefits of 5 percentage points, compared to 2.3 per cent for those without income loss (see column IV). Even if we control for tenure, wages and detailed industry affiliation prior to the crisis, outmigration is substantially higher for those who experienced a negative employment and earnings shock and who received UI benefits in 2009 (see columns II-III for men and V-VI for women) than for those with stable employment through the crisis. 
Table 4: Determinants of outmigration 2010-2012, pre-financial crisis labour migrants from Estonia, Latvia, Lithuania, and Poland

\begin{tabular}{|c|c|c|c|c|c|c|}
\hline & (I) & $\begin{array}{l}\text { (II) } \\
\text { Men }\end{array}$ & (III) & (IV) & $\begin{array}{c}\text { (V) } \\
\text { Women }\end{array}$ & $(\mathrm{VI})$ \\
\hline $\begin{array}{l}\text { Earnings shock and } \\
\text { UI benefits } 2009\end{array}$ & $\begin{array}{c}0.064 * * * \\
(0.009)\end{array}$ & $\begin{array}{c}0.063 * * * \\
(0.009)\end{array}$ & $\begin{array}{c}0.057^{* * *} \\
(0.009)\end{array}$ & $\begin{array}{c}0.052^{* * *} \\
(0.019)\end{array}$ & $\begin{array}{c}0.063 * * * \\
(0.019)\end{array}$ & $\begin{array}{c}0.063^{* * * *} \\
(0.019)\end{array}$ \\
\hline $\begin{array}{l}\text { Earnings shock w/o } \\
\text { UI benefits }\end{array}$ & $\begin{array}{c}0.305^{* * *} \\
(0.008)\end{array}$ & $\begin{array}{c}0.292 * * * \\
(0.008)\end{array}$ & $\begin{array}{c}0.268 * * * \\
(0.009)\end{array}$ & $\begin{array}{c}0.170^{* * *} \\
(0.014)\end{array}$ & $\begin{array}{c}0.166 * * * \\
(0.015)\end{array}$ & $\begin{array}{c}0.163^{* * * *} \\
(0.015)\end{array}$ \\
\hline $\begin{array}{l}\text { UI benefits 2009, } \\
\text { w/o earnings shock }\end{array}$ & $\begin{array}{l}-0.007 \\
(0.006)\end{array}$ & $\begin{array}{l}-0.007 \\
(0.006)\end{array}$ & $\begin{array}{l}-0.009 \\
(0.006)\end{array}$ & $\begin{array}{l}-0.007 \\
(0.010)\end{array}$ & $\begin{array}{l}-0.006 \\
(0.011)\end{array}$ & $\begin{array}{l}-0.007 \\
(0.011)\end{array}$ \\
\hline Tenure 2008 & & $\begin{array}{c}-0.010 * * * \\
(0.002)\end{array}$ & $\begin{array}{c}-0.005^{* *} \\
(0.002)\end{array}$ & & $\begin{array}{l}-0.005 \\
(0.004)\end{array}$ & $\begin{array}{l}-0.003 \\
(0.004)\end{array}$ \\
\hline $\begin{array}{l}\text { In(annual wages } \\
\text { 2008) }\end{array}$ & & & $\begin{array}{c}-0.057^{* * *} \\
(0.006)\end{array}$ & & & $\begin{array}{l}-0.009 \\
(0.007)\end{array}$ \\
\hline Constant & $\begin{array}{c}0.044^{* * *} \\
(0.003)\end{array}$ & $\begin{array}{c}0.045^{* * *} \\
(0.003)\end{array}$ & $\begin{array}{c}0.048^{* * *} \\
(0.003)\end{array}$ & $\begin{array}{c}0.023^{* * *} \\
(0.003)\end{array}$ & $\begin{array}{c}0.023 * * * \\
(0.003)\end{array}$ & $\begin{array}{c}0.023^{* * *} \\
(0.003)\end{array}$ \\
\hline $\begin{array}{l}\text { Additional control } \\
\text { variables }\end{array}$ & None & $\begin{array}{l}\text { Industry } \\
\text { (292 cat's) }\end{array}$ & $\begin{array}{l}\text { Industry } \\
\text { (292 cat's) }\end{array}$ & None & $\begin{array}{l}\text { Industry } \\
\text { (288 cat's) }\end{array}$ & $\begin{array}{l}\text { Industry } \\
\text { (288 cat's) }\end{array}$ \\
\hline
\end{tabular}

$* / * * * * *$ Significant at the 10/5/1 per cent level.

Note: Standard errors are reported in parentheses. Samples are restricted to those with wage earnings above $1 \mathrm{G}$ in 2008 and who were present in Norway 1.1.2010. The regressions have 12,982 (cols I-III) and 3,477 (cols IV-VI) observations. Where applicable, constant term is evaluated at sample mean of continuous variables and weighted average industry affiliation.

For those not claiming unemployment insurance, the adverse earnings shock raises the probability that the labour migrant outmigrates by as much as 27 percentage points for men and 16 percentage points for women (see Table 4, columns III and VI). These estimates are three to five times higher than for migrants who claimed UI benefits. Apparently, outmigration is strongly moderated by unemployment benefit eligibility. The unemployment benefit claim is, however, potentially endogenous. Even though we measure $\mathrm{UI}$ benefit receipt ahead of the period during which we study outmigration, some of those who claimed benefits during the financial crisis may have stayed for the long term even in the absence of unemployment insurance because they viewed employment prospects to be better in Norway than in the home country (refer back to the large cross-country differences in unemployment displayed in Figure 3). Moreover, the outcomes of non-claimants of benefits who also experienced a negative earnings shock during the crisis may not be a reasonable counterfactual for the alternative state without unemployment insurance. To study the isolated effect of unemployment insurance eligibility, we need a different identification strategy. Nevertheless, the data show that a small fraction of the labour migrants present in Norway during the crisis had outmigrated by 2013 (recall that only 7.2 per cent of men and 3.2 per cent of women 
remigrated). In contrast, a large fraction had collected unemployment insurance (as discussed above, fully 46 per cent of men and 27 per cent of women present in Norway at the end of 2009 received UI benefits at some point between 2009 and 2012). Such empirical patterns point to strong incentive effects of unemployment insurance: An overwhelming majority of the labour migrants who suffered job loss did not return to their home country. Instead, they stayed in Norway and collected UI benefits.

\section{Long-term earnings responses to negative employment shocks among immigrants and natives}

The prior section showed that the vast majority of the migrant cohorts under study chose to stay in Norway despite the downgrading of job opportunities. For the immigrants who chose to remain in Norway over time, it is of interest to investigate how the adverse shocks during the financial crisis affected their longer-term employment and earnings prospects (Åslund and Rooth, 2007, and Åslund et al., 2014, study long-term effects of initial labour market conditions and employment outcomes on immigrants earnings; Huttunen et al., 2011, investigate long-term effects of job loss in general). In Figure 6, we display average earnings profiles over time (excluding a few zeros) for the labour migrants employed in 2008 and still present in Norway at the end of 2012. Again, native samples match the age distribution of immigrants, and to ensure comparability the native samples are also restricted to those who were employed in 2008 and present in Norway on January 1, 2013.

Earnings growth reflects accumulation of experience as well as overall real wage growth. Earnings dips - or slowdown in growth - during the financial crisis in 2009 and 2010 are found for all groups considered. But, as Figure 6 shows, earnings dips are most pronounced for male immigrants. The average male migrant experienced a substantial decline in real labour earnings from 2008 to 2009. Earnings improved during the economic recovery of 2011 and 2012, with a slight convergence between the immigrants and low-educated natives. Compared to the average native male, however, the earnings gap remained at 34 per cent.

The financial crisis had less detrimental effects on earnings of female immigrants. Actually, earnings of immigrant women were, on average, slightly higher than those of low-educated native women throughout most of the study period. But, again, the immigrant-native comparison crucially depends on the comparison group. The average native female had somewhat higher earnings growth than the other groups considered from 2009 onwards. 


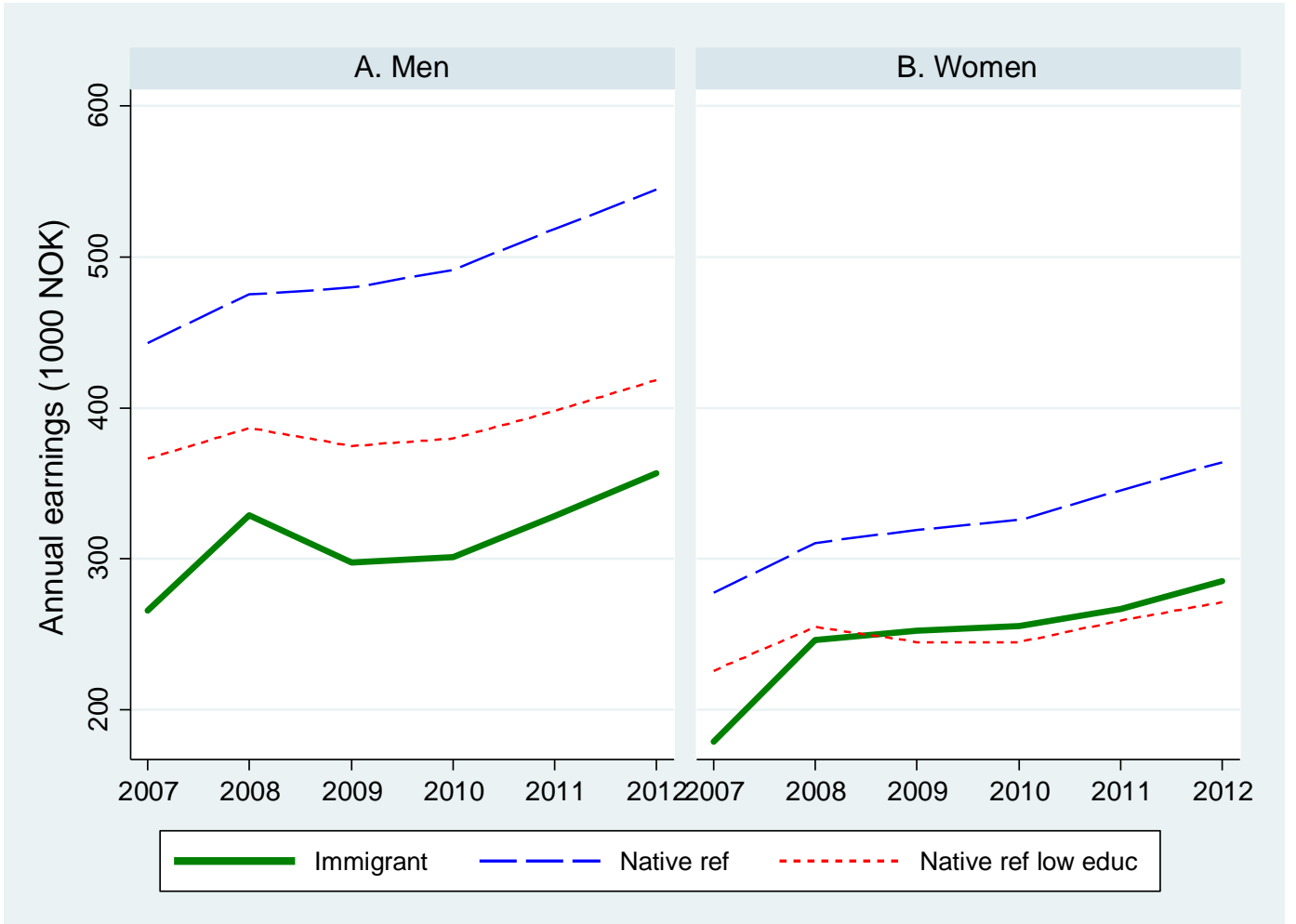

Figure 6: Average wage earnings, 2007-2012

Note: Immigrant samples consist of 2004-2007 migrants from Poland, Lithuania, Latvia, and Estonia; age 17-46 at arrival; employed in 2008 with labour earnings exceeding NOK 69,108; and present in Norway 1.1.2013. Native samples are subject to the same employment and earnings restrictions, and are stratified to match the age distribution of the immigrant samples. Averages exclude zero earnings. Earnings are inflated to 2011 values by the consumer price index.

To investigate the possible long-term consequences of the adverse earnings shocks in 2009, we next pool the samples of immigrant and native workers and regress the logarithm of 2012 earnings on an immigrant indicator variable and the 2009 individual shock measure, together with vectors of control variables. The coefficient attached to the immigrant indicator will then capture the immigrant-native earnings differential controlled for these other factors. The results are displayed in Table 5 . In the comparison with a representative sample of equally aged native workers, the observed earnings differentials are as high as $0.42 \log$ points for men and 0.32 log points for women; see panel A. Accounting for differences in 2012 industry affiliation and tenure reduces the native-immigrant differentials to 0.17 and 0.14 for men and women, respectively (see panel A, columns I and IV). Now, adding controls for the experience of an adverse shock in 2009 (including an indicator for receipt of unemployment benefits), reduces both the male and the female differential to 0.13 log points (columns II and V). Hence, particularly for men, it is clear that there are some - though not very large 
Table 5: Explaining immigrant-native difference in log 2012 wage earnings

\begin{tabular}{|c|c|c|c|c|c|c|}
\hline & (I) & $\begin{array}{l}\text { (II) } \\
\text { Men }\end{array}$ & (III) & (IV) & $\begin{array}{c}(\mathrm{V}) \\
\text { Women }\end{array}$ & $(\mathrm{VI})$ \\
\hline \multicolumn{7}{|l|}{ A. Vs. all natives } \\
\hline Observed difference & -0.415 & & & -0.323 & & \\
\hline $\begin{array}{l}\text { Immigrant-native } \\
\text { difference }\end{array}$ & $\begin{array}{c}-0.168^{* * *} \\
(0.010)\end{array}$ & $\begin{array}{c}-0.128^{* * *} \\
(0.010)\end{array}$ & $\begin{array}{c}-0.040 * * * \\
(0.009)\end{array}$ & $\begin{array}{c}-0.137 * * * \\
(0.017)\end{array}$ & $\begin{array}{c}-0.126 * * * \\
(0.017)\end{array}$ & $\begin{array}{c}-0.070^{* * *} \\
(0.016)\end{array}$ \\
\hline Earnings shock 2009 & & $\begin{array}{c}-0.416 * * * \\
(0.016)\end{array}$ & $\begin{array}{c}-0.256 * * * \\
(0.015)\end{array}$ & & $\begin{array}{c}-0.489 * * * \\
(0.025)\end{array}$ & $\begin{array}{c}-0.297 * * * \\
(0.025)\end{array}$ \\
\hline UI benefits 2009 & & $\begin{array}{c}-0.138^{* * *} \\
(0.011)\end{array}$ & $\begin{array}{c}-0.089 * * * \\
(0.011)\end{array}$ & & $\begin{array}{c}-0.225^{* * *} \\
(0.022)\end{array}$ & $\begin{array}{c}-0.177^{* * *} \\
(0.021)\end{array}$ \\
\hline Tenure & $\begin{array}{c}0.024 * * * \\
(0.001)\end{array}$ & $\begin{array}{c}0.021^{* * *} \\
(0.001)\end{array}$ & $\begin{array}{c}0.009^{* * *} \\
(0.001)\end{array}$ & $\begin{array}{c}0.044^{* * *} \\
(0.002)\end{array}$ & $\begin{array}{c}0.039 * * * \\
(0.002)\end{array}$ & $\begin{array}{c}0.023^{* * *} \\
(0.002)\end{array}$ \\
\hline $\begin{array}{l}\text { In(annual wages } \\
\text { 2008) }\end{array}$ & & & $\begin{array}{c}0.586^{* * *} \\
(0.007)\end{array}$ & & & $\begin{array}{c}0.453^{* * *} \\
(0.011)\end{array}$ \\
\hline \multicolumn{7}{|l|}{ B. Vs. low educ } \\
\hline Observed difference & -0.108 & & & 0.063 & & \\
\hline $\begin{array}{l}\text { Immigrant-native } \\
\text { difference }\end{array}$ & $\begin{array}{c}0.039 * * * \\
(0.014)\end{array}$ & $\begin{array}{c}0.050^{* * *} \\
(0.014)\end{array}$ & $\begin{array}{c}0.089 * * * \\
(0.013)\end{array}$ & $\begin{array}{c}0.134^{* * *} \\
(0.026)\end{array}$ & $\begin{array}{c}0.130 * * * \\
(0.026)\end{array}$ & $\begin{array}{c}0.138 * * * \\
(0.026)\end{array}$ \\
\hline Earnings shock 2009 & & $\begin{array}{c}-0.368 * * * \\
(0.021)\end{array}$ & $\begin{array}{c}-0.252^{* * *} \\
(0.020)\end{array}$ & & $\begin{array}{c}-0.564 * * * \\
(0.055)\end{array}$ & $\begin{array}{c}-0.408 * * * \\
(0.054)\end{array}$ \\
\hline UI benefits 2009 & & $\begin{array}{c}-0.061^{* * *} \\
(0.015)\end{array}$ & $\begin{array}{l}-0.028^{*} \\
(0.014)\end{array}$ & & $\begin{array}{c}-0.123 * * * \\
(0.039)\end{array}$ & $\begin{array}{c}-0.096^{* *} \\
(0.038)\end{array}$ \\
\hline Tenure & $\begin{array}{c}0.035^{* * *} \\
(0.002)\end{array}$ & $\begin{array}{c}0.029 * * * \\
(0.002)\end{array}$ & $\begin{array}{c}0.017^{* * *} \\
(0.002)\end{array}$ & $\begin{array}{c}0.054^{* * *} \\
(0.005)\end{array}$ & $\begin{array}{c}0.047^{* * *} \\
(0.005)\end{array}$ & $\begin{array}{c}0.030 * * * \\
(0.005)\end{array}$ \\
\hline $\begin{array}{l}\text { In(annual wages } \\
\text { 2008) }\end{array}$ & & & $\begin{array}{c}0.598 * * * \\
(0.014)\end{array}$ & & & $\begin{array}{c}0.524 * * * \\
(0.027)\end{array}$ \\
\hline $\begin{array}{l}\text { Additional control } \\
\text { variables }\end{array}$ & $\begin{array}{l}\text { Industry } \\
\text { (689 cat's) }\end{array}$ & $\begin{array}{l}\text { Industry } \\
\text { (689 cat's) }\end{array}$ & $\begin{array}{l}\text { Industry } \\
\text { (689 cat's) }\end{array}$ & $\begin{array}{l}\text { Industry } \\
\text { (612 cat's) }\end{array}$ & $\begin{array}{l}\text { Industry } \\
\text { (612 cat's) }\end{array}$ & $\begin{array}{l}\text { Industry } \\
\text { (612 cat's) }\end{array}$ \\
\hline
\end{tabular}

*/**/*** Significant at the 10/5/1 per cent level.

Note: Standard errors are reported in parentheses. Samples are restricted to those with labour earnings above $1 \mathrm{G}$ in 2008 and who were present in Norway 1.1.2013. The regressions have 45,886 (panel A, cols I-III), 24,307 (panel A, cols IV-VI), 20,942 (panel B, cols I-III), and 7,129 (panel B, cols IV-VI) observations.

- persistent negative impacts of the employment shocks of the financial crisis that raised the immigrant-native earnings differential on a lasting basis. Controlling for the initial earnings level in 2008 reduces the immigrant-native differential in 2012 even further, to 0.04 log point for men and 0.07 log points for women. Finally, it is clear from Table 5 that the 2009 adverse earnings shock had a lasting impact on individual earnings: controlling for the level of pre-crisis earnings, the 2012 
earnings of native men are $0.26 \log$ points and those of native women 0.30 log point lower than those who did not experience any individual employment shock during the financial crisis (see columns III and VI).

Moving further to the results based on the comparisons with low-education natives (see panel B), we find a similar pattern with respect to the impacts of the 2009 employment shock. Controlling for exposure to such shocks raises the earnings differential in favour of male immigrants. Indeed, accounting for differences in tenure and industry affiliation, it is evident that the immigrants on average have higher earnings than unskilled natives (see panel B, columns III and VI).

\section{Conclusions}

The opening up of the common labour market in Europe represents new opportunities for efficient allocation of labour, for reducing bottlenecks in production processes, for mitigating the fiscal consequences of demographic transition, and for cushioning national and regional cyclical fluctuations. However, at least in the short and intermediate terms, the integrated market also presents some political and economic challenges. A particular concern is that the large cross-country differences in wages and social insurance standards may put pressure on existing welfare state institutions. The fact that the social insurance benefit level in some countries by far exceeds typical wages in other countries may distort migration flows and weaken labour migrants' incentives to remain in productive employment over the long term. This makes the new European labour market qualitatively different from the common Nordic labour market that for 60 years has facilitated unrestricted labour mobility between countries, thereby raising aggregate output in the Nordic region.

In this chapter, we have examined the first major wave of post-EU accession labour migrants from Eastern Europe to Norway, with a focus on employment performance during the initial eight-year period after accession. We have shown that the labour immigrants were much more adversely affected by the financial crisis than comparable natives, and that during the winter months of 2008/09, immigrant unemployment rose spectacularly. Those who were directly affected by the crisis had a higher probability of remigration. Their outmigration propensity was moderate, however. For those who experienced job loss during the financial crisis, unemployment benefits were high compared to wages in their home country and many may have had rational expectations of returning to work in Norway. As predicted by theory, the return mobility of workers from the new EU member states seems less sensitive to negative employment shocks than what is previously found for interNordic migrants (Pedersen and Røed, 2008). 
Among those who stayed in Norway, the majority of unemployed immigrants returned to employment relatively quickly after the crisis, although the unemployment rate remained at a significantly higher level than for comparable natives even three years after the crisis. The adverse long-term earnings impacts of experiencing a negative labour demand shock during the financial crisis prevailed in 2012 and account for a significant portion of observed earnings differences between native and immigrant workers. Our findings reconfirm prior evidence in the empirical literature that recently arrived labour migrants are considerably more vulnerable to cyclical downturns than natives, and that they have a higher risk of persistent non-employment in the aftermath of negative labour demand shocks. For a majority of the immigrants studied, however, the unemployment experience turned out to be short-lived. Even if the lasting adverse effects of the financial crisis were moderate, the accumulated effects of business cycles on long-term employment profiles can be large when immigrants are consistently exposed to job loss during recessions.

\section{References}

Åslund, O., L. Hensvik, and O.N. Skans (2014), "Seeking similarity: How immigrants and natives manage in the labor market," Journal of Labor Economics, forthcoming.

Åslund, O., and D.O. Rooth (2007), "Do When and Where Matter? Initial Labor Market Conditions and Immigrant Earnings," The Economic Journal, Vol. 117, Issue 518, 422-448.

Barrett, A. (2012), "Welfare and Immigration," Migration Policy Centre Research Report 2012/07, European University Institute.

Barth, E., B. Bratsberg, and O. Raaum (2004), "Identifying Earnings Assimilation of Immigrants under Changing Macroeconomic Conditions," Scandinavian Journal of Economics 106(1): 1-22.

Barth, E., B. Bratsberg, and O. Raaum (2012), "Immigrant Wage Profiles within and between Firms," Labour Economics, Vol. 19, No. 4, 541-556.

Boeri, T. (2010), "Immigration to the Land of Redistribution," Economica, Vol. 77, No. 308, 651-687.

Bratsberg, B., J.E. Dølvik, and O. Raaum (2013), "Open Borders, Economic Shocks, and Work Migration," mimeo, Ragnar Frisch Centre for Economic Research.

Bratsberg, B., O. Raaum, and K. Røed (2010), "When Minority Labor Migrants Meet the Welfare State," Journal of Labor Economics, Vol. 28, No. 3, 633-676.

Bratsberg, B., O. Raaum, and K. Sørlie (2007), "Foreign-born migration to and from Norway," in C. Ozden and M. Schiff (eds), International Migration, Economic Development, \& Policy, New York: World Bank and Palgrave Macmillan. 
Dølvik, J.E., and L. Eldring (2008), Mobility of Labour from the New EU States to the Nordic RegionDevelopment Trends and Consequences, TemaNord 2008:537, Copenhagen: Nordic Council of Ministers) http://norden.org/pub/velfaerd/arbetsmarknad/uk/TN2008537.pdf.

Dustmann, C., A. Glitz, and T. Vogel (2010), "Employment, Wages, and the Economic Cycle: Differences between Immigrants and Natives," European Economic Review, Vol. 54, No. 1, 117.

Dustmann, C., and T. Frattini (2013), "The Fiscal Effects of Immigration to the UK," Discussion paper No 22/13, Centre for Research and Analysis of Migration, University College London.

Edin, P.A., R. J. LaLonde, and O. Åslund (2000), "Emigration of immigrants and measures of immigrant assimilation: Evidence from Sweden," Swedish Economic Policy Review 7, 163-204.

European Commission (2013), Practical guide on the applicable legislation in the European Union $(E U)$, the European Economic Area (EEA) and in Switzerland, Employment, Social Affairs and Equal Opportunities: Social Europe.

Friberg, J.H., and L. Eldring (2013), Labour migrants from Central and Eastern Europe in the Nordic countries. Patterns of migration, working conditions and recruitment practices, TemaNord 2013:570, Copenhagen: Nordic Council of Ministers (http://www.norden.org/no/publikationer/publikasjoner/2013-570).

Hansen, J., and M. Lofstrom (2003), "Immigrant Assimilation and Welfare Participation: Do Immigrants Assimilate into or out of Welfare?" Journal of Human Resources, Vol. 38, No. 1, 7498.

Hansen, N.W., Å.A. Seip, and L. Eldring (2010), Rekruttering av kompetansearbeidskraft fra tredjeland til Norden: Reguleringer, strategier og realiteter. TemaNord 2010:536. København: Nordisk Ministerråd

Holmøy, E., and B. Strøm (2012), “Gjør innvandring det lettere å finansiere velferdsstaten? “ $\varnothing$ konomiske analyser 3/2012, 37-45.

Husted, L., H.S. Nielsen, M. Rosholm, and N. Smith (2001), "Employment and wage assimilation of male first generation immigrants in Denmark," International Journal of Manpower 22, 39-68.

Huttunen, K., J. Møen, and K.G. Salvanes (2011), "How Destructive is Creative Destruction? Effects of Job Loss on Mobility, Withdrawal and Income," Journal of the European Economic Association 9 (5), 840-870.

Kennan, J. (2013), “Open Borders," Review of Economic Dynamics 16(2): L1-L13.

Lundborg, P. (2006), "EU Enlargement, Migration and Labor Market Institutions," Zeitschrift für ArbeitsmarktForschung 39(1): 24-34.

Mayda, Anna Maria (2010), "International Migrations: A Panel Data Analysis of the Determinants of Bilateral Flows," Journal of Population Economics, 23 (4), 1249-1274.

Nannestad, P. (2004), "Immigration as a Challenge to the Danish Welfare State?" European Journal of Political Economy, Vol. 20, No. 3, 755-767. 
Nekby, Lena (2006), "The emigration of immigrants, return vs onward migration: evidence from Sweden," Journal of Population Economics 19, 197-226.

NOU, Norges offentlige utredninger (2011:7), Velferd og migrasjon: Den norske modellens framtid. Oslo: Departementenes servicesenter.

Pedersen, P. J., M. Pytlikova, and N. Smith (2008), "Selection and network effects-Migration flows into OECD countries 1990-2000," European Economic Review 52(7), 1160-1186.

Pedersen, P.J., and M. Røed (2008), "A Survey of Earlier Studies of Intra Nordic Migration Flows," in Pedersen P.J., M. Røed and E. Wadensjö (eds), The Common Nordic Labour Market at 50, TemaNord 2008:506, Nordic Council of Ministers.

Preston, I. (2013), "The Effect of Immigration on Public Finances," Discussion paper No 23/13, Centre for Research and Analysis of Migration, University College London.

Sarvimäki, M. (2011), "Assimilation to a Welfare State: Labor Market Performance and Use of Social Benefits by Immigrants to Finland," Scandinavian Journal of Economics, Vol. 113, No. 3, 665688.

Sjaastad, L.A. (1962), "The Costs and Returns of Human Migration," The Journal of Political Economy 70: 80-93.

Storesletten, K. (2003), "Fiscal implication of immigration - a net present value calculation," Scandinavian Journal of Economics, Vol. 105, No. 3, 487-506.

Tronstad, K., and P. Andersson Joona (2013), "New patterns of migration from Central and Eastern Europe to the Nordic countries," in J.H. Friberg and L. Eldring (eds.), Labour migrants from Central and Eastern Europe in the Nordic countries. Patterns of migration, working conditions and recruitment practices, TemaNord 2013:570, Copenhagen: Nordic Council of Ministers. 